\title{
Decreased Carbon Monoxide Diffusing Capacity
}

National Cancer Institute

\section{Source}

National Cancer Institute. Decreased Carbon Monoxide Diffusing Capacity. NCI

Thesaurus. Code C78229.

A lung function test result in which the lung capacity to absorb carbon monoxide is decreased. 